\title{
Evaluation of Nootropic activity of Cressa cretica in scopola- mine- induced memory impairment in mice
}

\author{
Pragati Khare ${ }^{{ }^{*} \text {,Sudhir Chaudhary }}{ }^{1}$, Lubhan Singh ${ }^{1}$, Ghanshyam Yadav ${ }^{1}$, Shashi Verma ${ }^{2}$ \\ ${ }^{1}$ Department of Pharmaceutical Technology, Meerut Institute of Engineering and Technology, NH-58, \\ Bagpat Crossing, Bypass Road, Meerut, U.P.-250005, India \\ ${ }^{2}$ Department of Pharmacy, S.R.M.S (C.E.T), Bareilly, U.P., India \\ *Corresponding author E-mail: pragatikhare10@gmail.com
}

\begin{abstract}
The present investigation was undertaken to assess the pharmacological effects of Cressa cretica on learning and memory in mice. Morris water maze was used to test learning and memory. Two doses (200 and $400 \mathrm{mg} / \mathrm{kg}$, p.o.) of ethanolic extract of Cressa cretica were administered for 28 successive days in mice. The dose of $400 \mathrm{mg} / \mathrm{kg}$ p.o. of CCE (Cressa cretica extract) significantly enhanced learning and memory of mice. This dose significantly opposed the memory loss caused by Scopolamine $(0.4 \mathrm{mg} / \mathrm{kg}$, i.p. $)$. The effect of CCE on whole brain MDA, SOD, GSH, Catalase, NO activity was estimated to analyze how CCE shows nootropic activity. CCE reduced whole brain MDA, NO levels. Antioxidant properties and presence of flavonoids in Cressa cretica may be responsible for nootropic activity. Piracetam $(200 \mathrm{mg} / \mathrm{kg}$, i.p) was utilized as standard nootropic drug. Hence Cressa cretica seems to be a potent candidate for enhancing learning and memory and it would be beneficial for the treatment of amnesia and Alzheimer's disease.
\end{abstract}

Keywords: Cressa Cretica, Alzheimer's Disease (AD), Central Nervous System (CNS), Morris Water Maze (MWM), Malonyldialdehyde (MDA), Superoxide Dismutase (SOD), Nitric Oxide (NO).

\section{Introduction}

The Reactive Oxygen Species is an important mediator involved in the pathogenesis of psoriasis, atopic dermatitis and contact dermatitis, neurodegenerative disorders and causes the tissue injury by damaging macromolecules like lipid and proteins, lipid peroxidation of membranes.

Cressa cretica L. (Convolvulaceae), popularly known as 'Rudanti' in Hindi is a useful medicinal plant. Different parts of the plant have been claimed to be valuable in a wide spectrum of diseases (Rani S. and Chaudhary S., 2011). In earlier studies Cressa cretica Linn flowers exhibited cytotoxic and anti-inflammatory activity in vitro. Cressa cretica is reported to be antibilous, antituberculosis and expectorant (Chaudhary, 2012; Chaudhary, 2010). Shahat et al. yielded five flavonoids (quercetin, quercetin-3-O-glucoside, kaempferol-3-Orhamnoglucoside and rutin) from the aerial parts of Cressa cretica. The oil of C. cretica is safe for human consumption. In addition the antiviral activity from the plant was reported It is already reported that the arial parts of the plant contains scopoletin umbelliferone, isoflavone glycoside coumaranochrome glycoside, Syringaresinol glucoside and dicaffeoyl quinic acid were also isolated (Sunita, 2011).

Free radical formation takes place during cerebral ischemia. Brain is likely to be damaged by the oxidative stress. The oxidative stress may cause death of neurons due to ischemia. Many synthetic free radical scavengers have been investigated in animal models of ischemia and reperfusion and have been proved to be neuroprotective. However, the effect of dietary antioxidants on cerebral ischemia and reperfusion has not been evaluated. Therefore, the present study is designed to investigate the effect of die- tary flavonoid rutin, micronutrient selenium and garlic oil on ischemia and reperfusion-induced cerebral injury (Gupta, 2003). The accumulation of oxidative damage markers in the brain may lead to age-related memory loss. The brain is highly susceptible to be damaged by ROS, as about $20 \%$ of the body's total oxygen is required by the brain and consists a high amount of polyunsaturated fatty acids and lower levels of antioxidant activity in comparison to other tissues. Many enzymatic and non-enzymatic antioxidant protectives are present like superoxide dismutase (SOD), glutathione peroxidase (GPX), catalase (CAT), glutathione (GSH), vitamin C (Abreu, 2011).

Dementia is a mental illness where there is loss of intellectual ability. Dementia includes impairment of memory. Alzheimer's disease is the most common etiology for dementia, which is concerned with the loss of neurons in certain brain areas. Since allopathic system of medicine has not a perfect treatment, it is desirable to deal the disease with herbal medication, especially for the geriatric patients (Dhingra, 2004).

Nootropic drugs are a class of psychotropic drugs that enhance learning acquisition and reverse learning impairments in experimental animals, and are likely to be clinically effective in Memory Dysfunctions (Kumar, 2000).

\subsection{Geographical source}

C. cretica is a remarkable salt tolerant plant, common in coastal areas usually occurring in marshes. This plant is distributed throughout India, Timor, and Australia (Rani, 2011, Chaudhary, 2012, Chaudhary, 2010). 


\section{Materials and methods}

\subsection{Plant material}

The plant of Cressa cretica was collected from the sandy shores along the mangrove creeks near Devanampattinam Beach, Cuddalore district in Tamilnadu and authenticated (specimen number- 74052) by taxonomist Dr. K.Ravikumar FRLHT Bangalore. A voucher specimen of collected sample was deposited in the institutional herbarium for future reference.

\subsection{Preparation of extracts}

The plant of Cressa cretica was washed thoroughly in tap water, shade dried and powdered. This powder was packed into Soxhlet column and extracted with petroleum ether $\left(60-80^{\circ} \mathrm{C}\right)$ for $24 \mathrm{~h}$. The same marc was successively extracted with chloroform (50 $\left.60^{\circ} \mathrm{C}\right)$ and later with ethanol $\left(68-78^{\circ} \mathrm{C}\right)$ for $24 \mathrm{~h}$. The extracts were concentrated on water bath $\left(50^{\circ} \mathrm{C}\right)$. After concentrated preparation, the dried powder extract was stored at room temperature. The yield of the petroleum extract, chloroform extract and ethanolic extract were found to be $0.8 \%(\mathrm{w} / \mathrm{w}), 0.8 \%(\mathrm{w} / \mathrm{w})$ and $1.0 \%(\mathrm{w} / \mathrm{w})$ respectively. Ethanolic extract was used for the experimental study.

\subsection{Drug treatment}

The ethanolic extract was suspended in distilled water containing carboxy methyl cellulose (1\%w/v CMC) in doses of 200,400 $\mathrm{mg} / \mathrm{kg}$ p.o. for the pharmacological tests. The doses were selected based on the previous studies on the ethanolic extract. Cressa cretica extract (CCE) was administered to individual mice in group $4,5,7,8$. None of the mice was dead due to treatment till the end of the observation period. The Cressa cretica extract caused no abnormality till the duration of treatment.

\subsection{Animals}

Animals were procured from Central Animal House, MIET, and Meerut. Animals were approved by Institutional Animal Ethic Committee (IAEC) of MIET, Meerut. Approval number (711/02/a/CPCSEA/2011-12/14) was given for this work. The preferred rodent species included mice. Swiss albino strains of young healthy adult of either sex animals in equal numbers per group $(n=6)$ were taken. At the commencement of the study the weight variations of animals used was kept minimal and not exceeded $\pm 20 \%$ of the mean weight of each animal. Normal weight of mice was 25-30 gm.

The temperature of the experimental animal room was maintained to be $22^{\circ} \mathrm{C}\left( \pm 3^{\circ} \mathrm{C}\right)$. Relative humidity was maintained between 50 $60 \%$. Lighting was artificial, the sequence being 12 hours light, 12 hours dark. For feeding, conventional laboratory diets were used with drinking aqueous supplied ad libitum. Animals of same group were caged together. Healthy young adult of either sex mice were randomly assigned to the control, standard and treatment groups. The animals were identified uniquely (i.e., by marking at the base of the tail) and acclimatized for not less than 5 days in their cages prior to the start of the study.

\subsection{Drugs and chemicals}

Drugs: Piracetam and Scopolamine were purchased from Sigma Aldrich.

Chemicals: Petroleum ether, Ethyl Acetate, Ethanol, Chloroform, Methanol, were purchased from Central Drug House Laboratory (CDH).

\subsection{Vehicle}

The plant extract (CCE) was suspended in $1 \%$ w/v CMC and administered orally in mice. Scopolamine hydrobromide and Piracetam were dissolved separately in normal saline and injected i.p. Volume of oral administration and i.p. injection was $1 \mathrm{ml} / 100$ $\mathrm{g}$ of mouse.

\subsection{Exteroceptive behavioral models}

\subsubsection{Morris water maze}

The MWM task has been widely used to test the spatial learning and memory in rodents. It consist a large circular black pool of $120 \mathrm{~cm}$ in diameter, $50 \mathrm{~cm}$ height, filled to a depth of $30 \mathrm{~cm}$ with water at $27 \pm 2^{\circ} \mathrm{C}$. The pool was divided into four equal hypothetical quadrants and a platform of $8 \mathrm{~cm}^{2}$ was submerged $1 \mathrm{~cm}$ under the opaque surface in the center of one of the quadrant. The position of the Platform was kept same throughout the activity. The water should be colored and the maze painted black to hide the submerged platform.

The mice were placed into the water and permitted for $120 \mathrm{sec}$ to find out the platform. Mice received 2 trials per day with 20 minutes inter-trial interval for 4 days. The escape latency of each mouse was noted during each trial. The average of the escape latencies was taken out for each mouse and for each trial. Once the mouse found the platform, it was allowed to stay for $10 \mathrm{sec}$. If the mouse was unable to locate the platform within $90 \mathrm{sec}$, it was kept on the platform for $10 \mathrm{sec}$ and then removed from the morris water maze. The entry of the mouse into the pool and the location of the platform for escape remained unchanged between trials 1 and 2 but was altered on each day. The lowering of escape latency day by day in trial 1 represents long-term memory or reference memory while that from trial 1 to trial 2, shows the short-term memory (Chaudhary and Chauhan, 2012 and Sripanidkulchai et al, 2010).

48 mice were divided into 8 groups and each group had 6 mice. Separate animals were used for each experiment.

\begin{tabular}{|c|c|c|}
\hline Group & Treatment & Dose $(\mathrm{mg} / \mathrm{kg})$ \\
\hline 1 & Normal control treated with vehicle & \\
\hline 2 & $\begin{array}{l}\text { Positive group treated with } \\
\text { Piracetam }\end{array}$ & $200 \mathrm{mg} / \mathrm{kg}$, i.p \\
\hline 3 & $\begin{array}{l}\text { Negative control treated with sco- } \\
\text { polamine }\end{array}$ & $0.4 \mathrm{mg} / \mathrm{kg}$, i.p \\
\hline 4 & Extract low dose & 200mg/kg, p.o. \\
\hline 5 & Extract high dose & 400mg/kg, p.o. \\
\hline 6 & Positive control + Scopolamine & $200 \mathrm{mg} / \mathrm{kg}+0.4 \mathrm{mg} / \mathrm{kg}$, i.p \\
\hline 7 & Extract low dose + Scopolamine & $\begin{array}{l}200 \mathrm{mg} / \mathrm{kg}, \text { p.o.+ } \\
0.4 \mathrm{mg} / \mathrm{kg} \text {, i.p }\end{array}$ \\
\hline 8 & Extract high dose + Scopolamine & $\begin{array}{l}400 \mathrm{mg} / \mathrm{kg}, \text { p.o.+ } \\
0.4 \mathrm{mg} / \mathrm{kg} \text {, i.p }\end{array}$ \\
\hline
\end{tabular}

Group I: It represented the control group for young mice. Vehicle was administered orally for 28 successive days and transfer latency was measured after 90 min of administration on $28^{\text {th }}$ and again after 24 hr i.e. on $29^{\text {th }}$ day.

Group II: It represented the positive control group for young mice. Piracetam $(200 \mathrm{mg} / \mathrm{kg}$ i.p.) was injected to young mice for 28 successive days and transfer latency was measured after $60 \mathrm{~min}$ of administration on $28^{\text {th }}$ day and again after $24 \mathrm{hr}$ i.e. on $29^{\text {th }}$ day. Group III: It represented the negative control group for young mice. Scopolamine $(0.4 \mathrm{mg} / \mathrm{kg})$ was injected i.p. to young mice and transfer latency was measured $45 \mathrm{~min}$ after injection and again after $24 \mathrm{hr}$ (i.e. on $29^{\text {th }}$ day).

Group IV and V: CCE (200, $400 \mathrm{mg} / \mathrm{kg}$, p.o.) were administered orally to the young mice for 28 successive days. TL was recorded after 90 min of administration on $28^{\text {th }}$ day and again after $24 \mathrm{hr}$ i.e. on $29^{\text {th }}$ day.

Group VI: Piracetam $(200 \mathrm{mg} / \mathrm{kg}$, i.p. $)$ was injected for 28 successive days to young mice. At $60 \mathrm{~min}$ after the injection of piracetam on the $28^{\text {th }}$ day, scopolamine $0.4 \mathrm{mg} / \mathrm{kg}$, i.p. was administered. TL was noted after $45 \mathrm{~min}$ of administration of scopolamine and again after $24 \mathrm{hr}$ i.e. on $29^{\text {th }}$ day. 
Group VII, VIII: CCE (200, 400 mg/kg, p.o.) were administered p.o. to the mice for 28 days and Scopolamine $(0.4 \mathrm{mg} / \mathrm{kg})$ was administered intraperitoneally to mice at $90 \mathrm{~min}$. after the administration of CCE extract on $28^{\text {th }}$ day. TL was recorded $45 \mathrm{~min}$. after the scopolamine has been administered and after $24 \mathrm{~h}$ (i.e. on $29^{\text {th }}$ day).

\subsubsection{Actophotometer}

It is made up of six built in photo-sensors and 4-digits digitalcounter for the locomotor activity. It measures the movements of mice with the digital counter. When the beam of light falling on the photo cell is cut off by the animal, the count is recorded in the digital counter. Actophotometer can be used to test the locomotor activity of both rats $\&$ mice.

The CNS depressant drugs decrease the locomotor activity while the CNS stimulants enhance the locomotor activity. Actually, the locomotor activity indicates the alertness of the mental state. (Kulkarni, S.K 2010).

\subsection{Biochemical analysis for the estimation of oxidative damage markers}

\subsubsection{Brain tissue preparation}

Mice were euthanized by cervical dislocation to avoid any injuries to the brain tissue. Brain tissue samples were collected and homogenized 10 times (w/v) by homogenizer using ice-cold $0.1 \mathrm{M}$ phosphate buffer ( $\mathrm{pH}$ 7.4). The samples of mice brain homogenates were collected in different test tubes analyze protein, lipid peroxidation, Catalase, nitric oxide, SOD and glutathione. The supernatant was used for enzymatic assays. Using purified bovine serum albumin as standard the protein concentration was determined according to Lowry et al. (1951).

\subsubsection{Determination of superoxide dismutase (SOD) principle}

The enzyme is necessary for survival in all oxygen metabolizing cells. It is found in the cytosol and intermembrane space of mitochondria of eukaryotic cells. It contains copper and zinc. In normal cells this radical alone is the precursor of hydrogen peroxide. SOD's scavenges the superoxide (O2-) and thus provide a first line defiance against free radical damage. SOD is a family of metalloenzyme that catalyze the dismutase of superoxide anion $\left(\mathrm{O}_{2}\right)$ to hydrogen peroxide and molecular oxygen in the following manner.

$2 \mathrm{H}_{2} \mathrm{O}_{2}+2 \mathrm{O}^{-} \rightarrow 2 \mathrm{H}_{2} \mathrm{O}+\mathrm{O}_{2}$

In the erythrocytes the super oxide anion $\left(\mathrm{O}_{2^{-}}\right)$interacts with peroxides to form hydroxyl radicals $(-\mathrm{OH})$, which causes haemolysis in the absence of SOD activity. SOD measurement was carried out on the ability of SOD to inhibit spontaneous oxidation of epinephrine to adrenochrome.

Procedure

SOD was measured according to the method of Kagiyama et al. $100 \mu \mathrm{l}$ of brain supernatant was added to tris $\mathrm{HCl}$ buffer ( $\mathrm{pH} 8.5$ ). The final volume of $3 \mathrm{ml}$ was made up with the same buffer. 25 $\mu \mathrm{l}$ of Pyrogallol was added and alteration of absorbance at $420 \mathrm{~nm}$ was recorded at $1 \mathrm{~min}$ interval for $3 \mathrm{~min}$. The presence of SOD inhibited the increase in absorbance at $420 \mathrm{~nm}$ after the addition of Pyrogallol solution. The results were expressed as units of SOD per mg of protein.

$$
\text { C x Total Volume x } 1000
$$

$$
\text { SOD = }
$$

50 x Sample Volume x mg protein per ml

The homogenate supernatant was added to $0.5 \mathrm{mM}$ hypoxanthine, $0.5 \mathrm{mM}$ hydroxylamine and $0.01 \mathrm{U}$ xanthine oxidase in the buffer, containing $104 \mathrm{mM}$ potassium phosphate, $78 \mathrm{mM}$ sodium borate and $0.025 \mathrm{mM}$ EDTA $(\mathrm{pH} 7.0)$ at $37{ }^{\circ} \mathrm{C}$ for $30 \mathrm{~min}$ in a reaction volume of $100 \mu$ l. The reaction was ended by the addition of 0.2 $\mathrm{ml}$ of $16 \%(\mathrm{v} / \mathrm{v})$ acetic acid solution which contained $2.6 \mathrm{mM}$ sulfanilic acid and $38.6 \mu \mathrm{M}$ naphthyl ethylenediamine and the absorbance was recorded at $550 \mathrm{~nm}$ inorder to calculate the SOD level.

\subsubsection{Determination of catalase (CAT) principle}

In UV range, $\mathrm{H}_{2} \mathrm{O}_{2}$ shows a continual increase in absorption with decreasing wavelength. The decomposition of $\mathrm{H}_{2} \mathrm{O}_{2}$ can be followed directly by the decrease in absorbance at $240 \mathrm{~nm}$. The difference in absorbance per unit is a measure of catalase activity. Observation: Check absorbance at time interval of $(0,15,30,60$ and $120 \mathrm{sec}$.)

Procedure:

Catalase was measured according to the method of Claiborn et al. $0.1 \mathrm{ml}$ of supernatant was added to a cuvette which contained 1.9 $\mathrm{ml}$ of $50 \mathrm{mM}$ phosphate buffer ( $\mathrm{pH} 7$ ). To this buffer solution $1 \mathrm{ml}$ freshly prepared $30 \mathrm{mM} \mathrm{H} \mathrm{H}_{2} \mathrm{O}_{2}$ was added. The rate of breakdown of $\mathrm{H}_{2} \mathrm{O}_{2}$ was analysed at $240 \mathrm{~nm}$ by UV spectrophotometer. Catalase values are expressed in terms of $\mathrm{n}$ moles $\mathrm{H}_{2} \mathrm{O}_{2}$ consumed per min per mg protein. (Mohammad et al, 2012).

\subsubsection{Determination of GSH}

The protein in the sample was precipitated with $50 \%$ TCA and centrifuged at $1000 \mathrm{rpm}$ for $5 \mathrm{~min}$. The mixture of reactants contained $50 \mu \mathrm{l}$ of supernatant, $200 \mu \mathrm{l}$ of $0.2 \mathrm{M}$ Tris-EDTA buffer

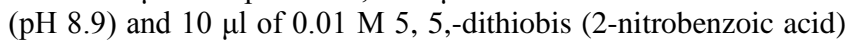
(DTNB). This mixture was placed for $5 \mathrm{~min}$. at room temperature and absorbance was taken at $412 \mathrm{~nm}$.

The GSH concentration was calculated using a GSH standard curve three times with ethanol: ethyl acetate $(1: 1 \mathrm{v} / \mathrm{v})$ mixture. The final protein pellet was dissolved in $6 \mathrm{M}$ guanidine hydrochloride and the absorbance was measured at $370 \mathrm{~nm}$.

\subsubsection{Determination of Malonyldialdehyde (MDA)}

The sensitivity of measuring Thiobarbituric Acid Reactive Substances (TBARS) has made this method of choice for screening and monitoring lipid peroxidation which is a major indicator of oxidative stress. Malondialdehyde (MDA) forms a 1:2 adduct with Thiobarbituric acid which was measured by spectrophotometer.

Procedure

MDA was measured according to the method of Ohkawa et al. 1 ml. of suspension medium was taken from the $10 \%$ tissue homogenate in a tube. $0.5 \mathrm{ml}$. of Trichloroacetic acid (TCA) was added to it, followed by $0.5 \mathrm{ml}$. of $8 \%$ Thiobarbituric acid (TBA) reagent. The tubes were covered with aluminum foil and kept in the water bath for $30 \mathrm{~min}$. at $80^{\circ} \mathrm{C}$. After $30 \mathrm{~min}$. the tubes were taken out and placed in the cold water for $30 \mathrm{~min}$. These tubes were centrifuged for $15 \mathrm{~min}$ at $3000 \mathrm{rpm}$. The absorbance of the supernatant was taken at $540 \mathrm{~nm}$, at room temperature against appropriate blank solution ( $1 \mathrm{ml}$ distilled water, $0.5 \mathrm{ml}$ of $30 \%$ TCA and $0.5 \mathrm{ml}$ of $0.8 \%$ TBA.). MDA value was expressed as $\mathrm{n}$ moles $\mathrm{MDA} / \mathrm{mg}$ of protein (Mohammad et al 2012).

\subsubsection{Determination of nitric oxide (NO)}

The production of nitric oxide was estimated by the accumulation of nitrate in the supernatant, which was determined by a colorimetric assay with the Griess reagent (1:1 solution of $1 \%$ sulfanilamide in $5 \% \quad \mathrm{H}_{3} \mathrm{PO}_{4}$ and $1 \%$ napthaylamine diamine dihydrochloric acid in water). Equal volume of the supernatant and the Griess reagent were mixed and this mixture was incubated for $10 \mathrm{~min}$ in dark at the room temperature. The absorbance was taken at $540 \mathrm{~nm}$ using spectrophotometer. The concentration of nitrite in the supernatant was estimated from a sodium nitrite standard curve.

\subsubsection{Protein estimation}

Protein was measured in all the brain samples. Bovine serum albumin (BSA) $(1 \mathrm{mg} / \mathrm{ml})$ was utilized as standard and measured in the range of $0.01-0.1 \mathrm{mg} / \mathrm{ml}$. 


\subsection{Statistical analysis}

The values were expressed as MEAN \pm SEM from 6 animals. The results were subjected to statistical analysis by using one-way ANOVA followed by Dunnett's test to calculate the significant difference if any among the groups. $\mathrm{P}<0.05$ was considered as significant.

\section{Results}

\subsection{Effect on escape latency (by Morris water maze)}

Escape latency (EL) of first day reflected learning behavior of animals whereas, EL of second day reflected retention of information or memory. Cressa cretica (200 and $400 \mathrm{mg} / \mathrm{kg}$ ) and Piracetam $(200 \mathrm{mg} / \mathrm{kg})$ administration for 28 successive days orally, intra-peritoneally respectively, significantly reduced EL on first day and also on second day, indicating significant improvement of learning and retention. Scopolamine $(1 \mathrm{mg} / \mathrm{kg})$ injected before training impaired the memory significantly as indicated by enhanced EL. Ethanolic extract of Cressa cretica (200 and 400 $\mathrm{mg} / \mathrm{kg}$ ) and Piracetam $(200 \mathrm{mg} / \mathrm{kg}$ ) administered orally for 28 days protected the mice from scopolamine-induced memory impairment.

\subsection{Actophotometer}

There was no significant change in the locomotor activity of mice.

\subsection{Biochemical estimation}

\subsubsection{MDA level}

Acquisition

netention

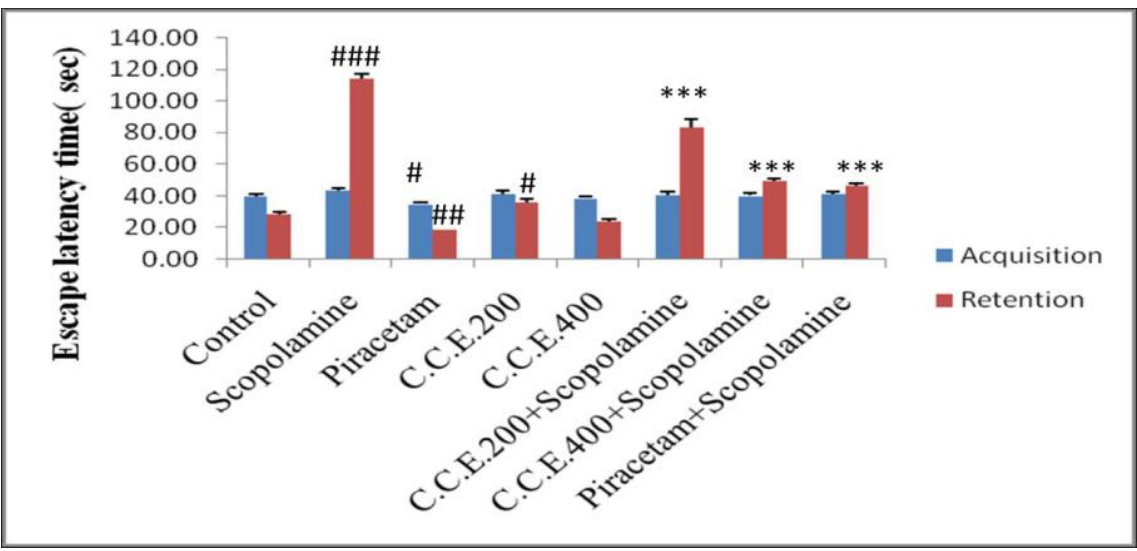

Fig. 1: Effect of Cressa Cretica on Morris Water Maze

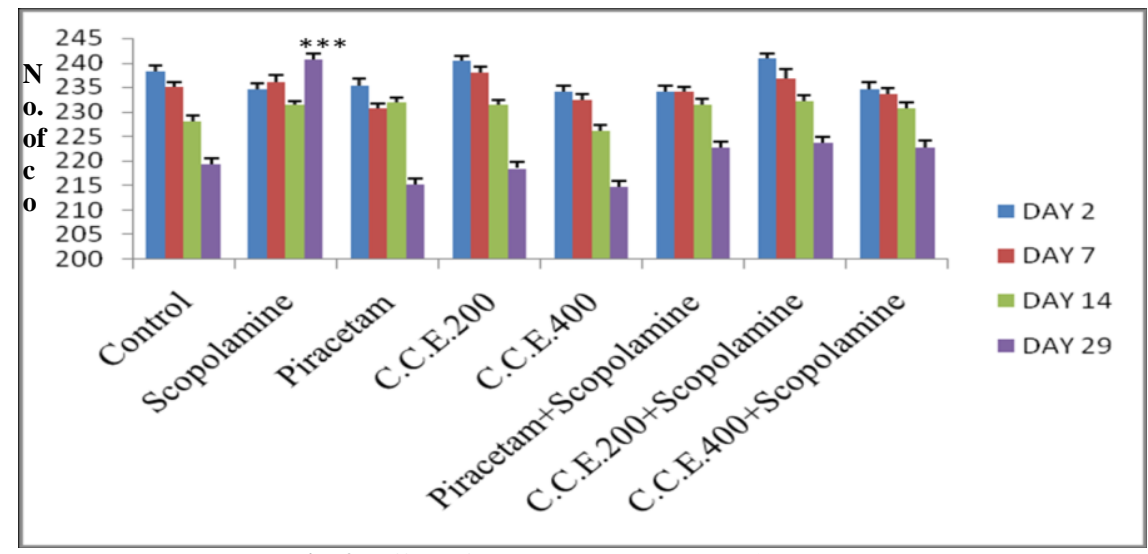

Fig. 2: Effect of Cressa Cretica on Actophotometer

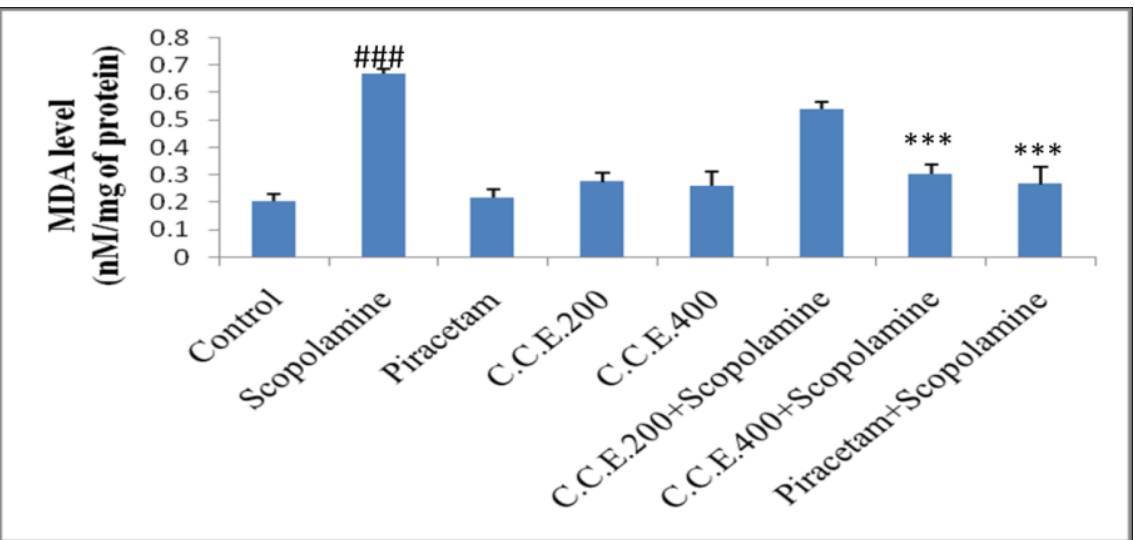

Fig. 3: Effect of Ethanolic Extract of Cressa Cretica on MDA Level 


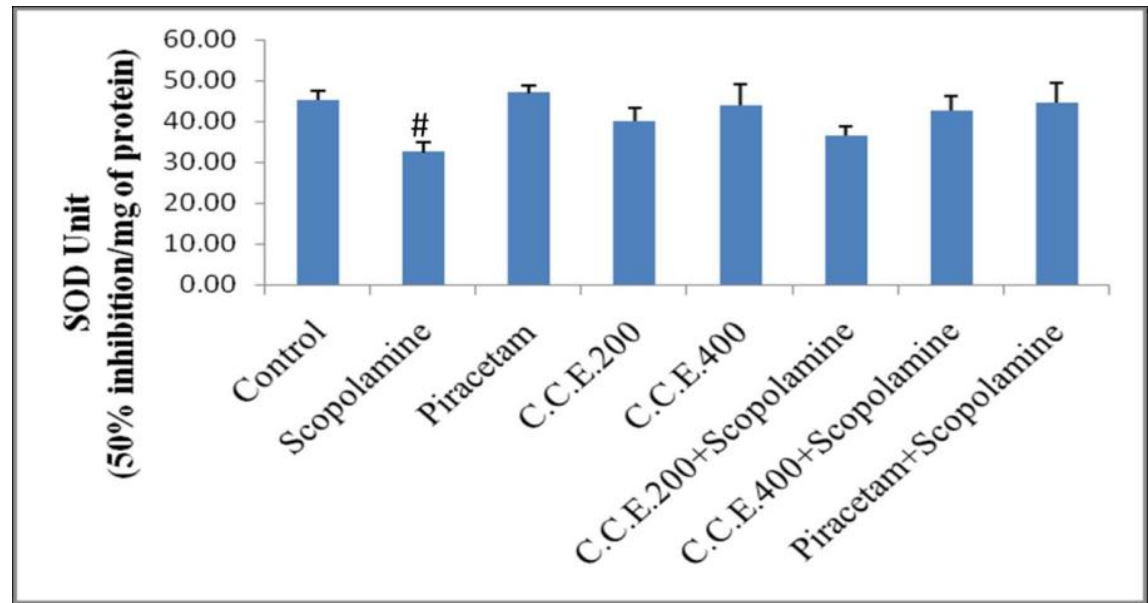

Fig. 4: Effect of Ethanolic Extract of Cressa Cretica on SOD Level

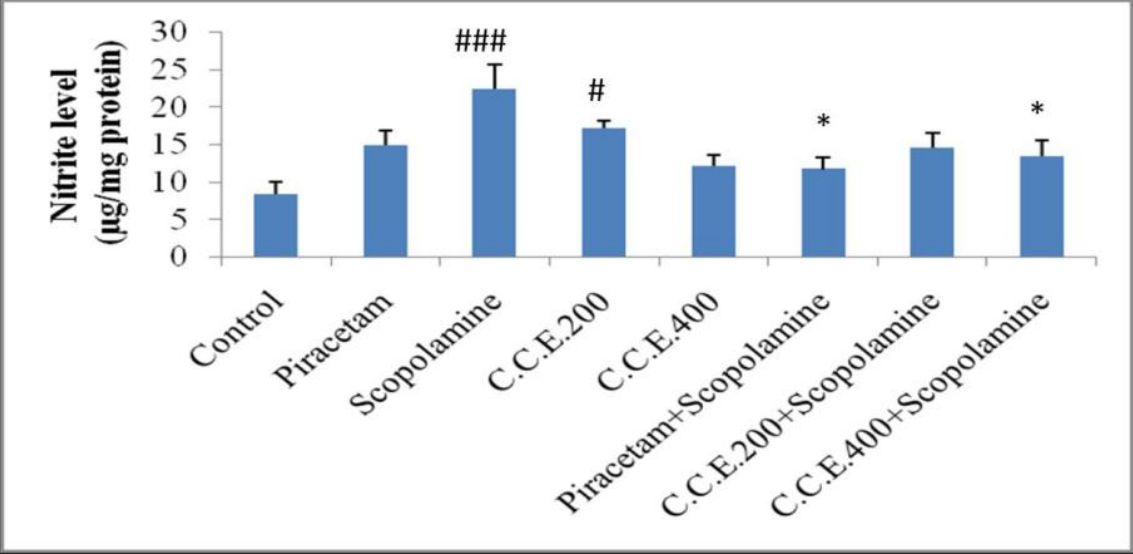

Fig. 5: Effect of Ethanolic Extract of Cressa Cretica on NO Level

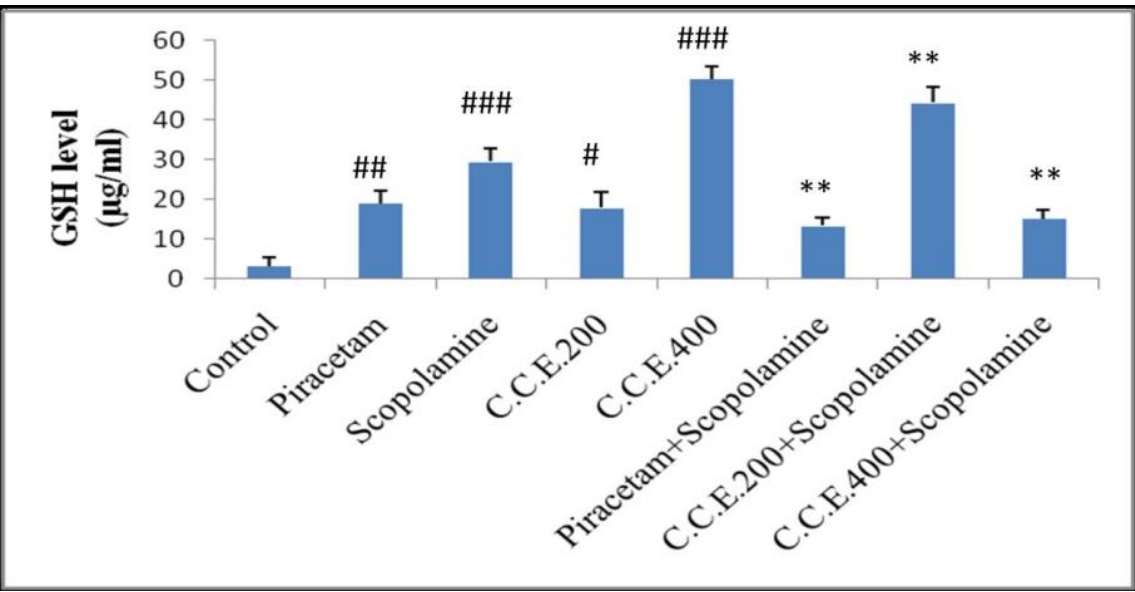

Fig. 6: Effect of Ethanolic Extract of Cressa Cretica on GSH Level

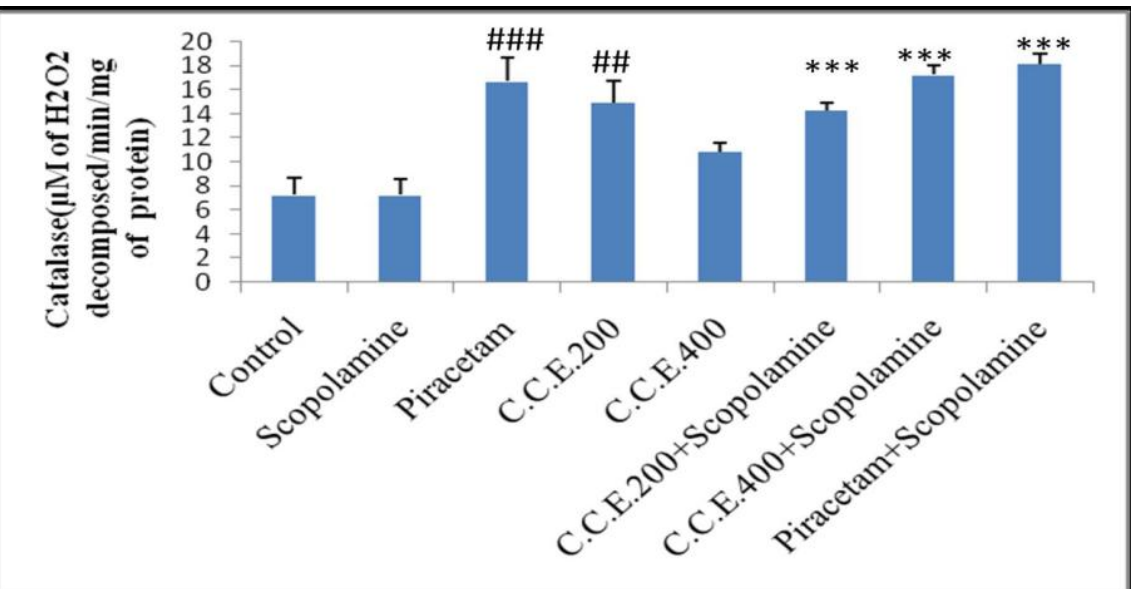

Fig. 7: Effect of Ethanolic Extract of Cressa Cretica on Catalase Level 
We have concluded that C.C.E. $(200,400 \mathrm{mg} / \mathrm{kg})$ dose showed significant decrease in MDA level. As a result, C.C.E. (200, 400 $\mathrm{mg} / \mathrm{kg}$ ) treated groups showed significant activity when compared to the scopolamine treated group.

\subsubsection{SOD level}

We have concluded that C.C.E. $(200,400 \mathrm{mg} / \mathrm{kg})$ dose showed significant increase in SOD level. As a result, C.C.E. (400, $200 \mathrm{mg} / \mathrm{kg}$ ) treated groups showed significant activity when compared to the scopolamine treated group.

\subsubsection{Nitric oxide}

We have concluded that C.C.E. $(200,400 \mathrm{mg} / \mathrm{kg})$ dose showed significant decrease in NO level. As a result, C.C.E. $(400,200$ $\mathrm{mg} / \mathrm{kg}$ ) treated groups showed significant activity when compared to the scopolamine treated group.

\subsubsection{GSH level}

We have concluded that C.C.E. (400mg/kg) dose showed significant increase in GSH level, but C.C.E. $(200 \mathrm{mg} / \mathrm{kg})$ did not show significant increase in GSH level. As a result, C.C.E. (400 mg/kg) treated group showed significant activity in comparison to the scopolamine treated group.

\subsubsection{Catalase level}

Effect of Cressa cretica extract on Catalase level

We have concluded that C.C.E. (200 mg/kg) dose showed significant increase in Catalase level, but C.C.E.400 (mg/kg) did not show significant increase in Catalase level. As a result, C.C.E. $(200 \mathrm{mg} / \mathrm{kg})$ treated groups showed significant activity when compared to the scopolamine treated group.

\section{Discussion}

Alzheimer's disease is a neurodegenerative disease. The symptoms are aphasia, apraxia and agnosia with the loss of memory. The allopathic system of medicine has to provide an effective therapy for this disease. In the present study CCE extract $(400 \mathrm{mg} / \mathrm{kg})$ administered orally for 28 days improved learning and memory of mice significantly in morris water maze test. In the Morris water maze test, the decrease in escape latency from day to day in trial 1 represents long-term memory while that from trial 1 to trial 2, represents short-term memory. Furthermore, pretreatment with CCE for 28 days protected the animals from scopolamine induced memory impairment. Reactive oxygen species are responsible for the age related degradation of cognitive performance which ultimately may cause Alzheimer's disease in elderly persons. Cressa cretica has been reported to possess antioxidant property as well. The neuroprotective effect of CCE may be due to its antioxidant property hence, the susceptible brain cells are exposed to lesser oxidative stress thereby reducing the brain damage. The symptoms of dementia are associated with the impaired neurotransmission in the affected brain regions. The plant of Cressa cretica contains flavonoids which may be responsible for memory enhancing activity.

\section{Conclusion}

From the results it can be concluded that ethanolic extract of plant of Cressa cretica at a dose of $400 \mathrm{mg} / \mathrm{kg}$ possess nootropic activity which is comparable to Piracetam. Cressa cretica pretreatment significantly prevented the rise in MDA, NO levels suggesting that it attenuates the excessive formation of reactive oxygen species (ROS). Cressa cretica causes enhancement in SOD, Catalase, GSH levels, thus prevents generation of free radicals. This is in agreement with the observations that Cressa cretica possesses significant nootropic activity.

\section{Acknowledgements}

We are thankful to the Management of Department of Pharmaceutical Technology, Meerut Institute of Engineering and Technology (M.I.E.T.), Meerut for providing chemicals and other infrastructure for doing this research work. The work is dedicated to all my teachers.

\section{References}

[1] Abreu, R.V., Oliveira, E.M., Moraes, M.F., 2011. Chronic coffee and caffeine ingestion effects on the cognitive function and antioxidant system of rat brains. Pharmacology, Biochemistry and Behavior, vol. 99, 659-664.

[2] Chaudhary, S and Khosa, R.L., 2010. Evaluation of antidiabetic activity of Cressa cretica Linn in alloxan induced diabetes in rats. Pharmacologyonline, vol. 3, 181-188.

[3] Chaudhary, S. and Khosa, R.L., 2012. A report on Pharmacognostical and quality control parameters of stem and root of Cressa cretica Linn, Convolvulaceae. Journal of Pharmacy Research, vol.5 (1), 616621.

[4] Chaudhary, S. and Khosa, R.L., 2010. Evaluation of antidiabetic activity of Cressa cretica Linn in alloxan induced diabetes in rats. Pharmacologyonline, vol. 3, 181-188.

[5] Chaudhary, A.K. and Chauhan, B., 2012. Memory enhancing activity of methanolic extract of Pterocarpus marsupium Roxb. Phytopharmacology, vol. 2 (1), 72-80.

[6] Dhingra, D., Parle, M. and Kulkarni, S.K., 2004. Memory enhancing activity of Glycyrrhiza glabra in mice. Journal of Ethnopharmacology, vol. 91, 361-365.

[7] Gupta, R.S. and Kachhawa, J.B.S., 2006. Effect of Cressa cretica Linn. methanolic extract on testicular function of albino rats. Pharmaceutical Biology, vol.44 (5), 382-88.

[8] Gupta, R., Singh, M. and Sharma, A., 2003. Neuroprotective effect of antioxidants on ischaemia and reperfusion-induced cerebral injury. Pharmacological Research, vol. 48, 209-215.

[9] Kulkarni S.K., 2010. Hand book of Experimental pharmacology. Vallabh prakashan.

[10]Kumar, V., Singh, P.N., Muruganandam, A.V. and Bhattacharya, S.K., 2000. Effect of Indian Hypericum perforatum Linn on animal models of cognitive dysfunction. Journal of Ethnopharmacology, vol. 72, 119-128.

[11]Sunita, P., Jha, S. and Pattanayak, S.P., 2011. Anti-inflammatory and In-vivo Antioxidant Activities of Cressa cretica Linn. A Halophytic Plant. Middle-East Journal of Scientific Research, vol. 8 (1), 129-140.

[12]Mohammad, A., Mohammad, M.A., Kalam, N.A, 2012. Ameliorating effects of two extracts of Nigella sativa in middle cerebral artery occluded rat. Journal of Pharmacy and Bioallide Sciences, vol. 4 (1), 7075 .

[13]Rani, S., Chaudhary, S., Singh, P. and Mishra, G., 2011. Cressa Cretica Linn: An Important Medicinal Plant-A Review on Its Traditional Uses, Phytochemical and Pharmacological Properties. J. Nat. Prod. Plant Resour. vol. 1 (1), 91-100.

[14]Sripanidkulchai, B., Sripanidkuchai K., Wyss, J.M. et al., 2010. Curcuma comosa improves learning and memory function on ovariectomized rats in a long-term Morris water maze test. Journal Ethnopharmacol, vol. 130 (1), 70-79. 